\title{
PENGEMBANGAN KOMPETENSI APARATUR SIPIL NEGARA DI LINGKUNGAN PEMERINTAH PROVINSI KALIMANTAN TIMUR
}

\section{COMPETENCE DEVELOPMENT OF CIVIL SERVANTS IN EAST KALIMANTAN PROVINCIAL GOVERNMENT}

\author{
Dewi Sartika dan Mayahayati Kusumaningrum \\ Pusat Kajian dan Pendidikan dan Pelatihan Aparatur III Lembaga Administrasi \\ Negara (PKP2A III LAN), Jalan HM Ardans (Ring Road III) Samarinda \\ Email: naurah10@yahoo.com,may.kaltim@gmail.com
}

Naskah diterima: 23 Mei 2017, revisi: 11 September 2017, disetujui: 11 September 2017.

\begin{abstract}
This study aims to describe the competence development of civil servants in East Kalimantan Provincial Government based on Law Number 5 Year 2014 and the factors that influence it. With qualitative descriptive method, secondary data is collected through library research. Result of the research is the comparison of the personnel posture, senior officer ratio based on gender, and the accomodation of the local people which is still relatively small; Competence development is still considered to be the domain of BKD and has not become a priority of regional government needs based on regional content. Competency development is still constrained by the lack of budget and managerial staff, the existence of inconsistent central policies that can not be followed by the region. Assessment is recomended toward the competencies which is relevant and required for senior leader level in order to arrange developed standards of managerial and socio-cultural competence. Competence development is not only concerned with the priority of accomodating local people to be apparatus, but also the vision of regional development. Capacity building should be based on the agency's key strategic objectives and performance indicators. Dynamic leadership regeneration is needed as well as competency mapping with respect to gender sensitivity and priority of local people / regional content. Thus, innovative laboratories are required in each region to make change project of every high-level leader sustainable.
\end{abstract}

Keywords: Competence Development, Civil Servant, East Kalimantan Provincail Government.

\begin{abstract}
Abstrak
Penelitian ini bertujuan untuk mendeskripsikan pengembangan kompetensi Aparatur Sipil Negara di Pemerintah Provinsi Kalimantan Timur, dari Undang-undang Nomor 5 Tahun 2014 serta faktor yang mempengaruhinya. Dengan metode deskriptif kualitatif, data sekunder dikumpulkan melalui penelitian kepustakaan. Hasil penelitian adalah
\end{abstract}


perbandingan antara postur kepegawaian, rasio Pimpinan Tinggi (pimti) berdasar gender, dan akomodir putra daerah yang masih tergolong kecil; layanan publik menunjukkan inovasi pelayanan publik telah berjalan dengan lebih baik ditandai dengan reformasi pada sistem pelayanan publik. Pengembangan kompetensi masih dianggap menjadi ranah $\mathrm{BKD}$ dan belum menjadi prioritas kebutuhan pemerintah daerah berbasis regional content, pengembangan kompetensi masih terkendala dengan minimnya anggaran dan tenaga pengelola, adanya kebijakan pusat yang inkonsisten yang tidak mampu diikuti oleh daerah. Direkomendasikan assesment terhadap kompetensi yang dianggap relevan dan dibutuhkan oleh pimti, untuk selanjutnya disusun standar kompetensi manajerial dan sosio kultural. Pengembangan kompetensi tidak hanya memperhatikan prioritas putra daerah, juga visi pengembangan daerah. Penguatan kapasitas sebaiknya didasarkan pada sasaran strategis dan indikator kinerja utama instansi. Perlu dilakukan regenerasi kepemimpinan yang dinamis, pemetaan kompetensi dengan memperhatikan kepekaan gender dan prioritas putra daerah/regional content secara tepat sasaran. Perlu dibuat laboratorium inovasi di setiap daerah sebagai proyek perubahan berkelanjutan setiap pimpinan tinggi di unit kerjanya.

Kata Kunci: Pengembangan Kompetensi, Aparatur Pemerintah, Pemerintah Provinsi Kalimantan Timur

\section{A. PENDAHULUAN}

Era tahun 2013 birokrasi masih berbasis peraturan (rule based birocracy) atau administrasi kepegawaian, era tahun 2018 diharapkan sudah menjadi birokrasi berbasis kinerja (performance based bureaucracy) atau manajemen SDM dan akhirnya pada era tahun 2025 menjadi birokrasi kelas dunia berbasis pengembangan potensi human (dynamic governance) yaitu birokrasi bersih, kompeten dan melayani. Sayangnya, saat ini diakui Menteri PAN dan RB, kualitas aparatur sipil negara (ASN) masih jauh dari yang diharapkan karena minimnya keahlian yang dimiliki serta sangat rendahnya motivasi ASN dalam melayani masyarakat. Dari 4.475 juta ASN, sebanyak 64 persennya hanya memiliki kemampuan administratif, bahkan menurut beliau pada pengangkatan PNS terakhir, hampir 58 persen berasal dari tenaga honorer yang berarti tidak ada tes kompetensi yang diikuti.

Rendahnya kompetensi aparatur pemerintah terutama pejabat pemerintah sangat dipengaruhi oleh sistem rekrutmen yang didominasi oleh pemerintah pusat dan terbatasnya anggaran pemerintah daerah. Semua ini menyebabkan beberapa kelemahan pada kedua sisi. bagi masyarakat akan pelayanan yang kurang berkualitas, bagi pemerintah tidak bisa mengemban amanat rakyat dengan optimal. Aparat, sebagai pejabat pemerintah, memiliki hak untuk mengembangkan karir, yang tidak bisa berkembang secara optimal. Di sisi lain, masyarakat mendapatkan pelayanan yang kurang berkualitas karena pemerintah tidak dapat melaksanakan amanah secara optimal. Akhirnya, kemajuan negara dan bangsa terhambat. Sebagai contoh, reformasi birokrasi di Indonesia tidak dapat berjalan seperti yang diharapkan dikarenakan rendahnya kompetensi aparatur pemerintah sehingga tidak mampu membawa perubahan signifikan dalam pelayanan publik, terutama di daerah. (Hadi Shubhan, 2014).

Lahirnya Undang-undang RI No. 5 tahun 2014 tentang Aparatur Sipil Negara (ASN) diharapkan membawa perubahan dalam tatakelola pemerintahan. Postur birokrasi yang diinginkan adalah Pegawai Negeri Sipil (PNS) yang jumlahnya proporsional sesuai rasio antara beban kerja dengan jumlah penduduk, luas wilayah dan karakteristik daerah yang perlu dikembangkan serta persentase belanja pegawai dalam Anggaran Pendapatan Belanja Negara (APBN)/Anggaran 
Pendapatan Belanja Daerah (APBD), professional, berintegritas tinggi, pelayan masyarakat. Salah satu turunan dari Undang-Undang (UU) No 5 Tahun 2014 adalah Peraturan Pemerintah (PP) Nomor 11 Tahun 2017 tentang Manajemen Aparatur Sipil Negara, diantaranya terkait jabatan pimpinan tinggi(JPT) yang harus memuat profil kompetensi, kualifikasi, kepangkatan, pendidikan dan pelatihan, rekam jejak jabatan dan integritas, serta persyaratan lain yang dibutuhkan. Pengisian JPT bersifat kompetitif dan terbuka. JPT berfungsi memimpin dan memotivasi setiap pegawai ASN pada instansi pemerintah melalui kepeloporan dalam bidang keahlian professional, analisis dan rekomendasi kebijakan dan kepemimpinan manajemen; pengembangan kerja sama dengan instansi lain; serta keteladanan dalam mengamalkan nilai dasar ASN dan melaksanakan kode etik dan kode perilaku ASN.

MenPAN RB menyampaikan bahwa JPT harus bergerak menjadi motor agen perubahan (agent of change) baik untuk para staf maupun instansi yang dipimpinnya. Pimpinan selain mampu memotivasi bawahan, juga mampu menunjukkan diri sebagai SDM yang smart (KEMENPAN-RB, 2017).Gubernur Kaltim, juga menegaskan bahwa Pemangku JPT, dituntut mampu menjadi motor agen perubahan, baik untuk para level dibawahnya maupun instansi yang dipimpinnya. Tidak hanya itu, tantangan yang akan dihadapi Indonesia yaitu Masyarakat Ekonomi Asean (MEA) membawa akselerasi dalam perubahan yang diharapkan dapat mempercepat proses reformasi administrasi, reformasi birokrasi, revolusi mental serta memastikan sektor berganda cukup kompetitif sehingga pemerintah dan masyarakat dapat bersaing dengan pelaku organisasi lain dimana kuncinya adalah pengembangan kompetensi ASN. Ini menjadi kunci dari pembangunan daerah yang ditegaskan Gubernur Provinsi Kalimantan Timur H. Awang Faroek Ishak (Rahmad, 2015).

Riset sederhana ini berupaya memberikan gambaran bagaimana pengembangan kompetensi ASN di lingkungan Pemerintah Provinsi Kalimantan Timur khususnya pada pemangku jabatan pimpinan tinggi (JPT) berdasarkan kesesuaian denganUU No. 5 tahun 2014 tentang ASN, serta faktor apa saja yang berpengaruh didalam pelaksanaannya.

\section{B. METODE PENELITIAN}

Penelitian ini menggunakan metodologi kualitatif dengan metode deskriptif. Metode deskriptif yaitu metode penelitian untuk membuat gambaran mengenai situasi atau kejadian, sehingga metode ini berkehendak mengadakan akumulasi data dasar belaka (Nazir, 2014). Metode deskriptif diawali dengan transkripsi kemudian diikuti dengan olah data reduction, data display, reviewing, dan pengambilan kesimpulan serta upaya untuk kembali memverifikasi data yang ada (Wirantha, 2012). Bertempat di Pemerintahan Provinsi Kalimantan Timur, pada tahun 2015.Teknik pengumpulan data sekunder dilakukan melalui desk research, yakni dilakukan tanpa melalui observasi lapangan, dimana hanya melalui penelusuran data online, serta pengumpulan data deskriptif dari hasil kajian sebelumnya. Sebagaimana dinyatakan oleh (Bungin, 2007), bahwa realitas sosial bentukan kontruksi sosial dapat dijadikan data kualitatif, yang salah satunya dapat dikumpulkan dengan metode wawancara, metode observasi, metode dokumenter, metode bahan visual dan metode penelusuran data online. Dari perolehan data tersebut selanjutnya dikembangkan dan dianalisis secara lebih mendalam.

\section{KERANGKA TEORI}

Paradigma baru manajemen SDM memandang pegawai sebagai aset organisasi bukan lagi sebagai modal (capital). Pencapaian tujuan organisasi berkaitan erat dengan pencapaian kinerja setiap SDM organisasi di dalamnya. Tentu dengan memperhatikan kompetensi dan keahlian unik setiap individu. Kompetensi merupakan persyaratan standar bagi seorang individu untuk melakukan 
pekerjaan tertentu dengan tepat dan benar. A competency is defined as a behavior or set of behaviors that describes excellent performance in a particular work context (Job Role, Position, or Function)((NLCM), 2017). Palan berpendapat bahwa (Palan, 2003): behavioural characteristics that describe motives, traits, self-concept, values, knowledge or skills that a superior performer brings to the workplace atau a competency can be defined as an underlying characteristics of an individual that is causally related to criterion referenced effective and/ or superior performance in a job or situation. Pendapat lain mengatakan competencies are behavior that encompass the knowledge, skills, and attributes required for succesfull performance.(Jordan, 2010).

Pengembangan SDM berbasis kompetensi mutlak dilakukan agar tujuan organisasi dapat tercapai. Kompetensi setiap individu dapat dilihat dari beberapa karakteristik sebagai berikut(Veithzal Rivai Zainal, 2015):

1. Motif, yaitu kebutuhan dasar atau pola pikir yang menggerakkan, mengarahkan, dan menyeleksi perilaku individual, misalnya kebutuhan untuk berprestasi

2. Sifat, yaitu bawaan umum untuk berperilaku atau merespons dengan cara tertentu, misalnya dengan kepercayaan diri, kontrol diri, resistensi stres atau "kekerasan”.

3. Konsep diri, yaitu sikap atau nilai yang diukur oleh tes responden yang menanyakan kepada orang apa yang mereka nilai, apa yang harus mereka lakukan, atau mengapa mereka tertarik dalam melakukan pekerjaan tersebut.

4. Content knowledge, ini berhubungan dengan fakta atau prosedur baik secara teknis ataupun personal, yang dapat diukur dengan tes responden

5. Keterampilan kognitif dan behavioral, baik yang tidak terlihat (misal: keterampilan berpikir deduktif/induktif) maupun yang dapat diamati secara langsung (misal: keterampilan mendengarkan secara aktif.

Kompetensi merupakan faktor penentu bagi seseorang dalam menghasilkan kinerja yang baik dan juga keberhasilan organisasi mencapai tujuan. Kompetensi sebagai kemampuan seseorang yang dapat terobservasi yang mencakup pengetahuan, keterampilan, dan sikap dalam menyelesaikan suatu pekerjaan atau tugas sesuai dengan perform yang ditetapkan. Ada beberapa pendekatan mengenai model kompetensi salahsatunya adalah competency-based HRM(manajemen SDM berdasarkan kompetensi).Terdapat delapan belas kompetensi secara umum pada berbagai bidang pekerjaan dan industri ; (1) Achievement orientation, (2)Analytical thinking, (3) Conceptual thinking, (4) Customer service orientation, (5) Developing others, (6) Directivenes, (7) Flexibility, (8) Impact and influence, (9) Information seeking, (10) Initiative, (11) Integrity, (12) Interpersonal understanding, (13) Organizational awareness, (14) Organizational commitment, (15) Relationship building, (16) Self-confidence, (17) Team leadership, (18) Teamwork and cooperation. Setelah berhasil membuat model kompetensi, perlu mengidentifikasi tingkat kompetensi yang dimiliki, dimana hasil akhirnya adalah profil kompetensi yang memuat tantangan stratejik dan perilaku yang dibutuhkan dan kompetensi yang dimiliki. Terdapat beberapa metode yang dapat digunakan untuk mengukur kompetensi, yaitu (Veithzal Rivai Zainal, 2015):

1. Behavior Event Interview (BEI)/Competency Based Interview, merupakan teknik interview yang memiliki tingkat akurasi tinggi dalam mengidentifikasi kompetensi yang dimiliki seseorang, yang dilakukan dengan mencari data yang detail dari pengalaman masa lalu seorang individu, misalnya tentang: Apakah yang dilakukan oleh seorang individu pada situasi tertentu; Apa yang dipikirkan dan dirasakan pada situasi tertentu; dan sebagainya. 
2. Tes, berbagai macam tes dapat dipakai untuk mengukur kompetensi, misalnya work-sample test, mental-ability test, dan personality test.

3. Assesment center, kompetensi dinilai oleh assesor, dimana penilaian tersebut dilakukan melalui pelaksanaan kegiatan seperti in-basket exercise, "stress" exercise, wawancara, presentasi mengenai visi, misi dan strategi atau leaderless group exercise.

4. Biodata, beberapa kompetensi dapat diprediksi berdasarkan pengalaman kerja seseorang, misalnya achievement motive, dengan melihat prestasi akademisnya, team leadership dari kegiatan organisasi yang dipimpinnya, atau relationship building dari kegiatan sosial yang diikutinya.

5. Rating, dapat diakukan oleh atasan, rekan kerja, bawahan, atau pun spesialis SDM/assesor. Sering disebut sebagai “ $360^{\circ}$ assessment”. Beberapa metode rating antara lain: competency assessment questionnaires, customer survey, managerial style, serta organizational climate.

ASN sebagai profesi yang memiliki kewajiban mengelola dan mengembangkan dirinya dan wajib mempertanggung-jawabkan kinerjanya dan menerapkan prinsip merit dalam pelaksanaan manajemen ASN. Fungsi ASN yaitu sebagai pelaksana kebijakan publik, pelayan publik, perekat dan pemersatu bangsa. Sedangkan tugas ASN itu sendiri adalah melaksanakan kebijakan publik yang dibuat oleh Pejabat Pembina Kepegawaian sesuai dengan ketentuan peraturan perundangundangan, memberikan pelayanan publik yang professional dan berkualitas serta mempererat persatuan dan kesatuan Negara Kesatuan Republik Indonesia.Peran vitalnya sebagai perencana, pelaksana dan pengawas penyelenggaraan tugas umum pemerintahan dan pembangunan nasional melalui pelaksanaan kebijakan dan pelayanan publik yang profesional, bebas dari intervensi politik, serta bersih dari praktik korupsi, kolusi dan nepotisme.

Ditilik dari jabatan ASN terdiri dari; 1) jabatan administrasi yang terbagi atas jabatan administrator, jabatan pengawas dan jabatan pelaksana; 2) jabatan fungsional yang terdiri dari jabatan fungsional keahlian dan jabatan fungsional ketrampilan; 3) jabatan pimpinan tinggi yang terdiri dari jabatan pimpinan tinggi utama, jabatan pimpinan tinggi madya dan jabatan pimpinan tinggi pratama.Kesemua jabatan diatas menuntut kualifikasi, kompetensi dasar dan kompetensi sesuai bidang tugas khusus jabatan administrator dan jabatan pimpinan tinggi membutuhkan kompetensi manajerial serta kompetensi sosial kultural. Selain itu, kepangkatan, pendidikan dan pelatihan, rekam jejak jabatan dan integritas serta persyaratan lain yang dibutuhkan. Pengembangan karier ASN dilakukan berdasarkan kualifikasi, kompetensi, penilaian kinerja, dan kebutuhan Instansi Pemerintah dengan mempertimbangkan integritas dan moralitas. Kompetensi ASN yang dimaksudkan meliputi: Pertama, kompetensi teknis yang diukur dari tingkat dan spesialisasi pendidikan, pelatihan teknis fungsional, dan pengalaman bekerja secara teknis; Kedua, kompetensi manajerial yang diukur dari tingkat pendidikan, pelatihan struktural atau manajemen, dan pengalaman kepemimpinan; dan ketiga, kompetensi sosial kultural yang diukur dari pengalaman kerja berkaitan dengan masyarakat majemuk dalam hal agama, suku, dan budaya sehingga memiliki wawasan kebangsaan.

Pengembangan karir ASN mempertimbangkan sisi integritas yang diukur dari kejujuran, kepatuhan terhadap ketentuan perundang-undangan, kemampuan bekerja sama, dan pengabdian kepada masyarakat, bangsa dan negara. Juga mempertimbangkan sisi moralitas yang diukur dari penerapan dan pengamalan nilai etika, agama, budaya dan sosial kemasyarakatan. Setiap pegawai ASN memiliki hak dan kesempatan untuk mengembangkan kompetensi dan harus dievaluasi oleh pejabat yang berwenang dan digunakan sebagai salah satu dasar dalam pengangkatan dalam jabatan dan pengembangan karir bagi PNS dan salah satu dasar untuk perjanjian kerja selanjutnya bagi Pegawai Pemerintah dengan Perjanjian Kerja (PPPK). Pengembangan kompetensi ini dilakukan 
antara lain melalui pendidikan dan pelatihan, seminar, kursus, dan penataran. Selain itu juga dapat dilakukan melalui pemberian kesempatan untuk melakukan praktik kerja di instansi lain di pusat dan daerah dalam waktu paling lama 1 (satu) tahun juga dengan melakukan pertukaran antara PNS dengan pegawai swasta dalam waktu paling lama 1 (satu) tahun. Kesempatan prioritas untuk pengembangan kompetensi dapat diberikan sebagai salah satu bentuk penghargaan kepada PNS atau PPPK yang telah menunjukkan kesetiaan, pengabdian, kecakapan, kejujuran, kedisiplinan, dan prestasi kerja dalam melaksanakan tugasnya. Kebutuhan dan rencana pengembangan kompetensi terdiri atas inventarisasi jenis kompetensi yang perlu ditingkatkan dari setiap PNS dan rencana pelaksanaan pengembangan kompetensi. Ini terkait dengan seleksi pengisian JPT baik di tingkat instansi maupun nasional. Rencana pengembangan kompetensi tersebut dilakukan untuk jangka waktu 1 (satu) tahun yang pembiayaannya tertuang dalam rencana kerja anggaran tahunan instansi. Sebagai bahan penyusunan rencana pengembangan kompetensi tersebut, dilakukan analisis kesenjangan kompetensi dan analisis kesenjangan kinerja. Analisis kesenjangan kompetensi dilakukan dengan membandingkan profil kompetensi PNS dengan standar kompetensi jabatan yang diduduki dan yang akan diduduki. Sedangkan analisis kesenjangan kinerja dilakukan dengan membandingkan hasil penilaian kinerja PNS dengan target kinerja jabatan yang diduduki. Pengembangan kompetensi ASN dapat dilakukan dalam bentuk: pertama, pendidikan dan kedua, pelatihan. Dalam bentuk pendidikan formal dilakukan untuk meningkatkan pengetahuan dan keahlian PNS sesuai ketentuan perundang-undangan dengan pemberian tugas belajar yang diberikan dalam rangka memenuhi kebutuhan standar kompetensi jabatan dan pengembangan karir. Prioritas pengembangan kompetensi diberikan dalam bentuk tugas belajar sebagai salah satu bentuk penghargaan atas pencapaian kinerja. Sehingga dapat dikatakan bahwa pemberian tugas belajar adalah bentuk pengembangan kompetensi instansional.

Pengembangan kompetensi dalam bentuk pelatihan, dilakukan melalui jalur pelatihan klasikal dan non-klasikal. Pelatihan klasikal dilakukan melalui proses pembelajaran tatap muka di dalam kelas, paling kurang melalui pelatihan, seminar, kursus dan penataran. Sedangkan jalur pelatihan non klasikal paling kurang meliputi e-learning, bimbingan di tempat kerja, pelatihan jarak jauh, magang dan pertukaran antara PNS dan pegawai swasta. Pengembangan kompetensi dapat dilaksanakan secara mandiri, oleh internal instansi pemerintah yang bersangkutan; bersama dengan instansi pemerintah lain yang memiliki akreditasi untuk melaksanakan pengembangan kompetensi tertentu; atau bersama dengan lembaga pengembangan kompetensi yang independen.

Penyusunan rencana pengembangan kompetensi manajerial dan kompetensi sosial kultural dilakukan oleh LAN. Penyusunan rencana pengembangan kompetensi teknis fungsional dilakukan oleh instansi pembina jabatan fungsional. Pelatihan teknis, manajerial dan sosio kultural dilaksanakan untuk mencapai persyaratan standar kompetensi jabatan dan pengembangan karier. Jenis dan jenjang pengembangan kompetensi teknis ditetapkan oleh instansi teknisyang bersangkutan, oleh lembaga pelatihan terakreditasi. Jenis dan jenjangpengembangan kompetensi fungsional ditetapkan oleh instansi pembina jabatan fungsional, oleh lembaga pelatihan terakreditasi. Pengembangan kompetensi sosial kultural ditetapkan oleh LAN, oleh lembaga pelatihan terakreditasi. Pengembangan kompetensi manajerial melalui jalur pelatihan dilakukan melalui pelatihan struktural, yang terdiri atas: 1) kepemimpinan Madya; 2) kepemimpinan Pratama; 3) kepemimpinan Administrator; dan 4) kepemimpinan Pengawas. Pelatihan struktural kepemimpinan Madya diselenggarakan oleh LAN. Pelatihan struktural kepemimpinan Pratama, Administrator dan Pengawas diselenggarakan oleh lembaga diklat pemerintah terakreditasi.

Dalam rangka menyamakan persepsi terhadap tujuan dan sasaran pembangunan nasional dilaksanakan pelatihan di tingkat nasional yang diikuti oleh Pejabat Pimpinan Tinggi Utama dan Pejabat 
Pimpinan Tinggi Madya yang dilaksanakan oleh LAN. Pelatihan dapat dilakukan melalui kerjasama dengan instansi lain. LAN bertanggung jawab atas pengaturan, koordinasi dan penyelenggaraan pengembangan kompetensi. Kebutuhan pengembangan kompetensi diolah dan diusulkan oleh BKN kepada LAN.Evaluasi pengembangan kompetensi dilaksanakan untuk menilai kesesuaian antara kebutuhan kompetensi manajerial dan kompetensi sosial kultural PNS dengan standar kompetensi jabatan dan pengembangan karir. Evaluasi pengembangan kompetensi manajerial dan kompetensi sosial kultural dilakukan oleh LAN. Evaluasi pengembangan kompetensi teknis dan fungsional disampaikan kepada Menteri melalui LAN. Hasil evaluasi pengembangan kompetensi nasional dipublikasikan dalam Sistem Informasi Pelatihan yang terintegrasi dengan Sistem Informasi ASN.

Penilaian kinerja didasarkan pada pemahaman mengenai knowledge, skill, ekspertise dan behaviour yang dibutuhkan untuk melaksanakan pekerjaan secara baik dan juga berdasarkan pada analisis yang lebih lanjut mengenai sikap dan perilaku yang bersesuaian dengan kriteria masingmasing area yang dimaksud. Analisis kompetensi bertujuan untuk mendefinisikan kriteria tersebut, dijalankan berbeda dengan analisis yang dijalankan untuk mendefinisikan prinsip-prinsip akuntabilitas, tugas-tugas utama dan tujuan. Hal biasanya sesuai dengan job holder.

Analisis kompetensi biasanya dilaksanakan dengan cara atau dengan teknik "wawancara terstruktur” (Michael Amstrong dalam (Abdussamad, 2017), meskipun pendekatan workshop dapat juga diadopsi dimana sejumlah ahli manajemen bersama-sama menganalisis sebuah pekerjaan atau job family. Berbagai literatur lain menunjukkan bahwa selain analisis kompetensi melalui wawancara terstruktur, ada juga teknik lainnya yang juga lazim digunakan adalah analisis kompetensi berdasarkan critical incident technique, repertory grid analysis dan job competence assessment. Dalam berbagai hasil kajian (Abdussamad, 2017) dari beberapa lembaga terkemuka, terdapat beberapa kompetensi yang paling tidak harus dimiliki oleh setiap pimpinan:

1. Development Dimentions International (DDI), membagi karakter kompetensi unggulan menurut lingkupnya, menjadi tiga kelompok yaitu lingkup organizational, lingkup team, dan lingkup personal.

2. Management Skill Analysis (MSA), didasarkan pada kerangka MEF (Management Excellence Framework) yaitu suatu kerangka manajemen paripurna yang terdiri dari duabelas (12) fungsi manajemen dan sepuluh (10) karakteristik manajemen unggulan. Konsep kompetensi dari MEF ini membagi level pegawai ke dalam tiga tingkatan yaitu eksekutif, manager, dan supervisor.

3. Civil Service College (CSC), Konsep Civil Service College (CSC) dapat digunakan untuk mencoba mengukur standar kompetensi sumber daya manusia a paratur pemerintah daerah. Konsep Civil Service College (CSC) membagi tiga level manajer yang mempunyai peran sebagai key result area. Hal ini bermanfaat untuk memfokuskan hasil dalam pekerjaan pegawai, dan membantu dalam merencanakan pekerjaan. Ketiga level tersebut meliputi:

a. Pertama, Manajemen Puncak, yang berpartiipasi dalam tim manajemen organisasi dan mengelola kegiatan untuk menjamin keberhasilan organisasi secara keseluruhan dan memberikan pelayanan kepada pelanggan;

b. Kedua, Manajemen Tingkat Menengah, mempunyai fungsi spesifik tim adalah menyampaikan pelayanan kepada pelanggan di dalam dan di luar organisasi sesuai dengan tujuan dan sasaran. Manajemen Tingkat Menengah menginterpretasikan dan mengimplementasikan strategi untuk mencapai hasil dan memberikan nasihat teknis dan tuntutan seluruh organisasi;

c. Ketiga, Manajemen Lini Pertama/Bawah, yang merupakan manajemen tingkat pertama dalam organisasi. Fokusnya adalah pemberian dukungan dan pelayanan kepada pelanggan (sektor internal dan eksternal) sehari-hari. 
Reformasi bidang manajemen publik berdampak pada tuntutan kualifikasi atau kompetensi sumber daya manusia aparatur sipil negara. Pengembangan SDM aparatur di sektor publik diarahkan kepada penataan kompetensi yang sesuai dengan bidang tugasnya. Persoalan utama yang dihadapi pemerintah pada semua tingkatan saat ini adalah karena sebagian besar bertumpu pada lemahnya kemampuan sumber daya manusia aparatur, baik pada level manajer, terlebih lagi pada sumber daya manusia non manajerial. (Abdussamad, 2017). Pada level manager, kelemahan yang umumnya dihadapi adalah terutama pada kurangnya pemahaman terhadap kualifikasi yang seharusnya dimiliki oleh setiap level manager dalam organisasi. Dalam konteks ini, kualifikasi yang dimaksud sebenarnya adalah adanya standar kompetensi yang disepakati bersama.

Beberapa faktor kunci keberhasilan (critical success factors) meliputi pengembangan sistem kepegawaian yang "unified", proporsional dan rasional, pengembangan sistem manajeman kepegawaian yang mampu mengantisipasi perkembangan lingkungan stratejik, dan memantapkan profesionalitas ASN yang seimbang dengan kebutuhan organisasi, pengembangan karier dan kesejahteraan pegawai. Pengembangan sistem kepegawaian yang unified, proporsional dan rasional sebagai bagian dari refomasi sistem kepegawaian (Personnel System Reform) yang bertujuan terwujudnya demokratisasi, desentralisasi dan pengembangan sistem kepegawaian yang dititikberatkan kepada "merit system”, mengarahkan sistem pengembangan sumber daya aparatur dengan sasaran utama untuk menjelaskan kinerja pegawai sesuai dengan standar kompetensi melalui kajian organisasional, okupasional maupun individual, dan menyusun desain prakondisi sistem kepegawaian, antara lain: 1) Penyusunan klasifikasi jabatan ASN secara rasional, sebagai bahan penyusunan peta jabatan pada setiap satuan organisasi baik pusat maupun daerah; 2) Penyusunan standar kompetensi jabatan ASN sebagai tolok ukur kinerja ASN; dan 3) Penyusunan sistem penilaian kinerja pegawai yang berorientasi pada standar kompetensi dan misi organisasi.

Penetapan standar kompetensi juga merupakan langkah mempertegas dan memperjelas kualifikasi dalam melaksanakan tugas-tugas atau tanggung jawabnya sesuai dengan kompetensi. Kompetensi memiliki multifungsi yang berguna sebagai acuan dalam rangka: seleksi (selection/ recruitment), kompensasi (compensation), observasi/pelatihan (observation/coaching), penilaian kinerja (performance appraisal), penilaian kebutuhan pendidikan dan organisasi (organizational alignment), perencanaan karier (career planning), perencanaan suksesi (succession planning), dan promosi/penempatan (promotion/placement). Pengembangan sumber daya aparatur (SDA) yang didasarkan pada standar kompetensi memerlukan adanya penyesuaian-penyesuaian dalam penyelenggaraan pendidikan dan pelatihan aparatur. Arah,pendekatan dan materi diklat pegawai negeri sipil dalam mengatasi kesenjangan kompetensinya (competency gap). Oleh karena itu, strategi penyelenggaraan diklat ASN diarahkan pada diklat yang didasarkan pada kompetensi (competencebased training).

Riset (Fadilla Astra, 2016) meneliti bahwa tingkat kompetensi kepemimpinan aparatur sipil Negara secara signifikan dipengaruhi oleh pengembangan kompetensi aparatur yang diikuti yaitu diklat kepemimpinan/struktural sebesar 74\% dan 26\% ditentukan variabel lain. (Rosianton Herlambang, 2014) dalam penelitiannya mengenai pengembangan kompetensi SDM menyimpulkan bahwa pengembangan kompetensi SDM membawa perubahan dengan peningkatan kontribusi dan kelancaran tugas serta mendorong motivasi pegawai untuk berprestasi, sedangkan faktor penghambat dalam pengembangan kompetensi aparatur berupa responsivitas pegawai dalam memanfaatkan kesempatan untuk pengembangan kapasitas dan kompetensi, keragaman pandangan diantara pegawai untuk mengembangkan kompetensi, dan terbatasnya alokasi anggaran untuk meningkatkan kompetensi pegawai. 
Riset lain menyoroti masalah sumber daya manusia di Indonesia yaitu distribusi pegawai negeri yang belum tersebar secara merata berdasarkan kompetensi, dan masih banyak akumulasi pegawai negeri di daerah kota. Penelitian ini mendeskripsikan dan menilai peran lembaga khusus pegawai daerah khusus DIY dalam pelaksanaan pembangunan sipil. Penelitian ini menggunakan metodologi kualitatif, dimana objek penelitian ini adalah Badan Kepegawaian Daerah yang merupakan salah satu praktik terbaik dalam pengembangan pegawai negeri. Temuan dari penelitian ini menunjukkan bahwa pengembanganpegawai dapat melalui beberapa hal diantaranya adalah: pendidikan dan pelatihan, rotasi dan promosi posisi (Koeswayo, 2014)

\section{HASIL DAN PEMBAHASAN}

Kondisi postur kepegawaian Pemerintah Provinsi Kalimantan Timur masih jauh dari kondisi ideal. Dengan jumlah penduduk sebesar 3.351.432 jiwa pada tahun 2014 (BPS, 2017) dan jumlah pegawai Pemerintah Provinsi Kalimantan Timur di laman website Badan Kepegawaian Daerah Provinsi Kalimantan Timur, tercatat hingga Desember 2014, jumlah pegawai di Provinsi Kaltim sebanyak 7.163 pegawai. Dari 7.163 PNS, sebanyak 4.619 atau 64,48 persen-nya merupakan pegawai golongan III dan IV, dimana pejabat struktural-nya berjumlah 1.164 pegawai dan sebanyak 1.301 pegawai telah mengikuti Diklatpim. (BKD, 2009). Hingga Desember 2014, jumlah pegawai Jabatan Fungsional Tertentu (JFT) sebanyak 1.310 pegawai dan meningkat di Maret 2015 menjadi 1.977 pegawai.Secara lengkap komposisi PNS di Provinsi Kalimantan Timur, sebagaimana tersaji dalam tabel berikut:

Tabel 1.

Rekap PNS Provinsi Kalimantan Timur berdasarkan eselonisasi

(Desember 2014)

\begin{tabular}{|l|l|l|l|}
\hline \multicolumn{2}{|c|}{ Berdasar Eselon } & \multicolumn{2}{c|}{ Berdasar Golongan } \\
\hline \multicolumn{1}{|c|}{ Jumlah } & \multicolumn{1}{c|}{ Golongan } & \multicolumn{1}{c|}{ Jumlah } \\
\hline Es I & 1 & Gol I & 389 \\
\hline Es II & 62 & Gol II & 2155 \\
\hline Es III & 310 & Gol III & 3849 \\
\hline Es IV & 791 & Gol IV & 770 \\
\hline Jumlah Eselon & 1164 & & \\
\cline { 1 - 2 } Non Eselon & 5999 & 7163 \\
\hline Total PNS & & \\
\hline
\end{tabular}

Sumber: BKD Provinsi Kalimantan Timur, 2015

Besarnya jumlah pegawai yang bergolongan III dan IV, cukup banyaknya pegawai struktural yang telah didiklatkan serta adanya upaya peningkatan jenjang pendidikan pegawai mengindikasikan bahwa sebagian besar pegawai memiliki tingkat pengetahuan dan kompetensi (serta pengalaman) yang relatif cukup tinggi dalam menjalankan tugas-tugas pemerintahan dan pembangunan daerah. Berdasarkan data PNS Provinsi Kaltim, jika dilihat dari tingkat pendidikannya, PNS Provinsi Kaltim paling banyak berpendidikan SLTA (2.489 pegawai atau 34,75 persen) dan berpendidikan S1 (2.140 pegawai atau 29,88 persen), sedangkan yang berpendidikan S2 dan S3 sebanyak 766 pegawai atau 10,69 persen dari total PNS. Perlu peningkatan kesadaran untuk pengembangan kualitas dan kapasitas dari sisi tingkat pendidikan, dan sepanjang 2009-2014 telah ada 745 pegawai yang melaksanakan tugas belajar maupun ijin belajar, dimana untuk tahun 2014 sebanyak 116 pegawai 
yang melaksanakan tugas belajar maupun ijin belajar baik untuk jenjang D3, S1, S2, dan S3. Rekapitulasi kepegawaian berdasarkan tingkat pendidikan disajikan dalam tabel berikut :

Tabel 2.

Rekap PNS Provinsi Kalimantan Timur berdasarkan tingkat pendidikan(Desember 2014)

\begin{tabular}{|l|r|r|r|}
\hline \multirow{2}{*}{ Pendidikan } & \multicolumn{2}{|c|}{ Gender } & \multirow{2}{*}{ Jumlah } \\
\cline { 2 - 3 } & Pria & \multicolumn{1}{|c|}{ Wanita } & 14 \\
\hline S3 & 13 & 1 & 752 \\
\hline S2 & 509 & 243 & 2140 \\
\hline S1 & 1258 & 882 & 154 \\
\hline D IV & 81 & 73 & 324 \\
\hline SM & 115 & 209 & 741 \\
\hline D III & 257 & 484 & 3 \\
\hline D II & 1 & 2 & 64 \\
\hline D I & 29 & 35 & 2489 \\
\hline SLTA & 1666 & 823 & 263 \\
\hline SLTP & 218 & 45 & 219 \\
\hline SD & 177 & 42 & $\mathbf{7 1 6 3}$ \\
\hline Jumlah & $\mathbf{4 3 2 4}$ & $\mathbf{2 8 3 9}$ & \\
\hline
\end{tabular}

Sumber: BKD Provinsi Kalimantan Timur, data diolah

Jumlah jabatan pimpinan tinggi (level eselon I dan eselon II), berdasarkan data per Desember 2014 menyebutkan sebanyak 62 pegawai di eselon II dan 1 pegawai eselon I, termasuk di dalamnya 11 perempuan di eselon II. Ini menunjukkan Kaltim terbuka bagi kepemimpinan perempuan, bahkan di tingkat eselon di bawahnya,33 persen dijabat oleh perempuan.

Sebagaimana Visi pembangunan Provinsi Kalimantan Timur (Kaltim Maju 2018) adalah "Mewujudkan Kaltim Sejahtera yang merata dan Berkeadilan berbasis Agroindustri dan Energi Ramah Lingkungan”. Untuk mewujudkan visi tersebut, Kaltim memfokuskan diri pada 5 misi-nya, yakni:

1. Mewujudkan kualitas Sumber Daya Manusia Kaltim;

2. Mewujudkan daya saing Ekonomi yang berkerakyatan berbasis SDAdan Energi terbarukan;

3. Mewujudkan infrastruktur dasar yang berkualitas bagi masyarakat secara merata;

4. Mewujudkan tata kelola pemerintahan yang professional dan berorientasi pada pelayanan publik; 5. Mewujudkan kualitas lingkungan yang baik dan sehat serta berperspektif perubahan iklim.

Dalam mencapai visi Kaltim Maju tersebut, upaya mewujudkan tata kelola pemerintahan yang professional dan berorientasi pada pelayanan publik menjadi fokus/prioritas pemerintah. Mengacu pada visi daerah dan kontribusi perekonomian daerah, pengembangan SDM di lapangan usaha/ sektor unggulan Kaltim menjadi kebutuhan daerah. Sehingga Pimti pratama harus mampu menerjemahkan visi misi Kepala daerah dalam Rencana Pembangunan Jangka Menengah Daerah (RPJMD) yang diturunkan ke dalam Renstra SKPD dan dalam kebijakan strategisnya.Pengembangan karir pegawai diukur terhadap empat hal, yaitu kualifikasi, kompetensi, prestasi kerja dan penilaian lainnya untuk kebutuhan organisasi. Upaya pengembangan kompetensi aparatur yang dilakukan Pemprov Kaltim, dilakukan dengan membuat pemetaan kompetensi. Salah satunya dengan melakukan tes pengukuran kompetensi PNS.(BKD, 2014). 
Pengukuran kompetensi yang telah dilaksanakan Pemprov Kaltim dilakukan bagi pejabat eselon II, pejabat eselon III, pejabat eselon IV, PNS golongan III/c ke atas. Kompetensi yang diukur meliputi kompetensi umum, kompetensi khusus dan kompetensi manajerial. Data dari BKD, menyebutkan dari 2.733 pegawai, 1.508 pegawai telah mengikuti pengukuran kompetensi. Selain para pejabat struktural, sebanyak 1.574 PNS golongan III/c akan diukur kompetensinya.Dari hasil pengukuran kompetensi, rata-rata eselon II di Kaltim lemah dalam pengambilan keputusan dan dalam penguasaan IT, bahkan untuk eselon III hanya sekitar 30 persen yang menguasai Teknologi Komunikasi.

Selain melakukan tes kompetensi bagi para pejabat struktural dan PNS III/c, Pemprov juga telah melakukan penataan pendidikan formal pegawai, yakni dengan melakukan tes bagi pegawai baik dari jalur tenaga honorer dan umum dengan status ijin belajar dan tugas belajar untuk kesesuaian antara pendidikan, syarat jabatan, dan kompetensi yangdimiliki dengan jabatan (BKD, 2015). Hingga tahun 2014 telah diberikan ijin dan tugas belajar kepada 745 pegawai yangmengajukan ijin dan tugas belajar. BKD juga telah menginventarisir rencana kebutuhan pendidikan formal di setiap SKPD hingga tahun 2017.

Pengukuran kompetensi merupakan dasar dalam menentukan arah pengembangan kompetensi ASN, hasil dari pengukuran ini akan menunjukkan pada aspek mana pengembangan kompetensi perlu untuk dilakukan. Pemprov Kaltim secara umum telah melaksanakan pengukuran kompetensi, sebagaimana yang telah disebutkan oleh (Veithzal Rivai Zainal, 2015) bahwa terdapat beberapa metode yang dapat digunakan untuk mengukur kompetensi, yaitu ; (1) Behavior Event Interview (BEI)/Competency Based Interview, (2) Tes, (3) Assesment center, (4) Biodata, (5) Rating. Adapun aspek yang menjadi kriteria berdasarkan penjelasan UU No 5/ 2015, pasal 69 dinyatakan bahwa untuk mengukur kompetensi ASN didasarkan pada ; Pertama, kompetensi teknis yang diukur dari tingkat dan spesialisasi pendidikan, pelatihan teknis fungsional, dan pengalaman bekerja secara teknis; Kedua, kompetensi manajerial yang diukur dari tingkat pendidikan, pelatihan struktural atau manajemen, dan pengalaman kepemimpinan; dan ketiga, kompetensi sosial kultural yang diukur dari pengalaman kerja berkaitan dengan masyarakat majemuk dalam hal agama, suku, dan budaya sehingga memiliki wawasan kebangsaan.

Pengembangan kompetensi ASN yang dilakukan Pemprov Kaltim salah satunya melalui kegiatan pelatihan, dan pengikutsertaan dalam seminar dan lainnya.Hal ini selaras dengan UU ASN, yang menyebutkan bahwa setiap pegawai ASN memiliki hak dan kesempatan untuk mengembangkan kompetensidan harus dievaluasi oleh pejabat yang berwenang. Pengembangan kompetensi ini dilakukan antara lain melalui pendidikan dan pelatihan, seminar, kursus, dan penataran, melalui jalur pelatihan klasikal dan non-klasikal. Pelatihan klasikal dilakukan melalui proses pembelajaran tatap muka di dalam kelas, paling kurang melalui pelatihan, seminar, kursus dan penataran. Sedangkan jalur pelatihan non klasikal paling kurang meliputi e-learning, bimbingan di tempat kerja, pelatihan jarak jauh, magang dan pertukaran antara PNS dan pegawai swasta.

Disamping itu, guna mewujudkan aparatur yang memiliki integritas, dedikasi dan disiplin tinggi terhadap pekerjaannya, Pemprov Kaltim telah melaksanakan presensi online untuk mengantisipasi terhadap penyimpangan pertanggungjawaban presensi manual, serta manajemen pengelolaan kinerja seperti Sasaran Kinerja Perorangan (SKP), hal ini bertujuan untuk menterjemahkan kinerja berbasis Peraturan Pemerintah No.53 dan Pergub 31 Tahun 2008. Dimana perbaikan 'mindset' aparatur dan peningkatan budaya kerja organisasi tampaknya menjadi prioritas perubahan yang dilakukan agar kinerja aparatur meningkat. Perubahan-perubahan ini diharapkan akan mampu meningkatkan semangat dan kinerja aparatur. 
Komitmen pemerintah Kaltim dalam mewujudkan tata kelola pemerintahan yang profesional dan berorientasi pada pelayanan publik tercermin dari perbaikan dan pembangunan sarana prasarana pengelolaan dan pengembangan kepegawaian seperti gedung BKD, gedung Bandiklat, gedung Assesment Center dan lainnya mengarahkan pada upaya menciptakan aparatur profesional yang berintegritas, berkinerja tinggi, adaptif, bebas dan bersih dari KKN, mampu melayani publik, netral, sejahtera, serta berdedikasi (BKD, 2015).

Wujud semangat perbaikan pengelolaan kepegawaian Kaltim terbukti dengan diterimanya BKNAward di tahun 2015. Selain dalam hal pengelolaan kepegawaian, Kaltim juga diakui (mendapat peringkat) dalam hal pelayanan mutasi kepegawaian, implementasi SAPK, menjadi BKD Provinsi yang inovatif, diakui juga dalam hal perencanaan kepegawaiannya serta implementasi penilaian kinerja. Semangat dan komitmen yang berkelanjutan serta terobosan dan inovasi manajemen kepegawaian penting agar dalam melaksanakan pengelolaan ASN tetap patuh pada norma, standar, prosedur dan kriteria (NSPK) (BKD, 2016).Karenanya, kinerja diukur berdasarkan jabatan yang diamanahkan masing-masing. Pola pemberian reward dan punishmentditerapkan BKD tergantung kreatifitas pimpinan. Terkait dengan pengembangan kompetensi Manajerial dan Sosio Kultural, BKD saat ini sedang mempersiapkan mapping talent pool, untuk seluruh eselon, saat ini baru selesai untuk seluruh eselon 3 karena keterbatasan anggaran dan minimnya lembaga sertifikasi yang merupakan kewenangan BKN baik itu sertifikasi dan akreditasinya. Demikian pula halnya dengan pola karir sudah diterapkan dengan bantuan kerjasama dengan LAN.

\section{Pengembangan Kompetensi Manajerial}

Standar Kompetensi Jabatan telah BKD susun meskipun belum ada payung hukumnya. Namun BKD memandang masih perlunya diklat soft problem atau diklat pengambilan keputusan. Ini diupayakan agar menyederhanakan mata rantai pengambilan keputusan. Penguatan ini karena otoritas yang sudah jelas dan SOP nya sudah dibuat. Visi profesionalisme yang dibangun dengan kriteria. Pertama, mengerti tugas pokok dan fungsi, kedua, memahami basic knowledge, ketiga, mengetahui dan menjalankan SOP yang sudah dibangun, keempat, dukungan sarana prasarana yang memadai.

Dalam wawancaranya, Kepala Bandiklat Provinsi Kaltim (Dewi Sartika, 2015) menjabarkan beberapa hal sebagai berikut : Pertama, Inovasi merupakan komponen kompetensi yang sangat dibutuhkan di Kaltim meskipun komponen tersebut dirasakan unggul di Kaltim. Selain itu, integritas dan kemampuan menerjemahkan visi misi kepala daerah ke dalam RPJM yang kemudian diturunkan ke Renstra SKPD dan diaplikasikan dalam program dan kegiatan. Kedua, Manajemen Perubahan. Ini menjelaskan bagaimana pimti beradaptasi dengan perubahan bahkan pada level yang paling sederhana dan kecil. Ketiga, kemampuan bernegoisasi dengan Pembina. Dalam artian, bagaimana menerjemahkan yang menjadi kehendak pimpinan dan bernegoisasi dengannya dalam hal menghindari tarikan kepentingan serta mengutamakan kesejahteraan masyarakat.

Sebagai contoh, Pembina Kepegawaian kebetulan adalahWalikota atau Bupati, ingin membangun infrastruktur gedung pertunjukan harganya 300 milyar tapi di sisi lain, masyarakat membutuhkan infrastruktur air bersih di kecamatan-kecamatan. Sebagai kepala Dinas PU atau pimti pratama harus bisa bernego kepada pemimpin, kompetensi manajerial dalam hal perencanaan dari bawah (musrenbang) usulan masyarakat perlu jaringan air bersih, atau jaringan internet, maka sebagai pimti pratama harus bisa menegoisasikannya kepada pimpinan Perlunya perubahan mindset bahwa yang dibutuhkan untuk menggerakkan roda organisasi adalah bulatnya pemahaman akan visi dan misi. Dari level pimpinan puncak hingga ke level terbawah. Demikian halnya dengan kemampuan memahami kultur masyarakat yang dilayani dalam konteks lokal. 
Sejak tahun 2012, BKD Provinsi Kalimantan Timur telah melakukan kegiatan pengukuran kompetensi pegawai, hal ini dilakukan dalam rangka reformasi birokrasi, yaitu mengubah pola pikir budaya kerja dan manajemen pemerintahan menuju terciptanya tata kelola pemerintahan yang baik. Selain itu, dengan dilakukan pengukuran kompetensi akan di dapatkan kompetensi yang diinginkan sesuai dengan kebutuhan organisasi sehingga dapat memberikan pelayanan yang optimal kepada masyarakat maupun stakeholder. Dimana, pada kegiatan tersebut juga melihat 17 (tujuh belas) jenis dalam kompetensi manajerial mulai dari kompetensi strategic thinking, integritas, inovasi, kerjasama sampai dengan berorientasi pada pelayanan dan kualitas. Hal ini tidak hanya bisa dimanfaatkan oleh pihak Pembina Kepegawaian sebagai bahan pertimbangan untuk peta jabatan dan pola karir, namun bagi pegawai sebagai motivasi untuk mengembangkan kompetensinya.

Pada tahun 2014, Pemerintah Provinsi Kalimantan Timur melaksanakan kegiatan Transformasi Budaya Organisasi bekerjasama dengan PKP2A III LAN. Hal ini dilakukan dalam meningkatkan kinerja aparatur di lingkungan Pemerintah Provinsi Kalimantan Timur. Dalam tahapan awal Kegiatan Transformasi Budaya adalah merumuskan nilai-nilai yang akan membawa organisasi menjadi lebih baik dengan melibatkan seluruh pegawai baik pimpinan tinggi maupun fungsional umum dengan metode/cara menggunakan pendekatan teori Edward De Bono yaitu "Six Thinking Hat" yang dipandang efektif dengan menggunakan analogi topi. De Bono mengajak untuk berpikir pararel dalam menemukan nilai-nilai organisasi yang akan ditingkatkan dan diimplementasikan.Alhasil, dirumuskan 4 core values (integritas, profesional, team work, dan koordinasi) di lingkungan Asisten Administrasi Umum Pemerintah Provinsi Kalimantan Timur yang yang perlu segera di tindaklanjuti. Dalam kaitannya kompetensi manajerial pimpinan tinggi, kegiatan transformasi budaya merupakan hal yang wajib dilakukan agar pimpinan tinggi meningkatkan semua unsur dalam kompetensi manajerialnya.

Pembentukan Team Building Transformasi Budaya Organisasi dan Budaya Kerja sebagai tindaklanjut kesepakatan Rapat Koordinasi Penegakan Hukum Disiplin Pegawai Negeri Sipil di Lingkungan Pemprov Kaltim, demi percepatan reformasi birokrasi di lingkungan Pemprov Kaltim guna mewujudkan tata kelola pemerintahan yang baik (good governance), dengan tujuan utama meningkatkan pelayanan prima kepada masyarakat. Kegiatan ini dilaksanakan berdasarkan Peraturan Menpan dan RB Nomor 39/2012 tentang Pedoman Pengembangan Budaya Kerja dan Pergub Kaltim Nomor 86/2012 tentang Pedoman Pelaksanaan Program Budaya Kerja di lingkungan Pemprov Kaltim, serta Surat Plt Sekretaris Daerah Kaltim pada 15 Juli 2013 Nomor 067/6363/ ORG tentang Pelaksanaan Percepatan Penerapan Budaya Kerja di lingkungan Pemprov Kaltim 2013. Pemprov Kaltim pada 11 September 2014 telah melakukan kesepakatan bersama yaitu seluruh pejabat struktural eselon II (pimpinan SKPD) lingkup Pemprov Kaltim dengan menandatangani pakta integritas komitmen bersama penerapan budaya kerja disiplin PNS. Komitmen tersebut berisi tentang penerapan kehadiran kerja PNS tepat waktu dengan sanksi pemotongan TPP, penerapan pakaian dinas lengkap, penerapan tertib administrasi keuangan, penerapan SKP (Sasaran Kinerja Pegawai) dan penerapan kehadiran rapat tepat waktu. Diharapkan dapat menularkan model-model transformasi budaya organisasi dan budaya kerja ke seluruh SKPD lingkup Pemprov Kaltim. Terutama untuk empat core value (nilai inti), yaitu profesional, integritas, kepedulian dan team work yang didapat peserta selama pelaksanaan team building ini.(BPSDM, 2014)

Tantangan manajerial terpenting dalam mewujudkan agenda Nawa Cita menurut para pimpinan tinggi Kaltim adalah (1) Pengambilan keputusan yang cepat dan tepat, (2) Pemberantasan praktik korupsi, kolusi dan nepotisme, (3) Membangun profesionalisme bawahan dalam menjalankan tugas, (4) Tuntutan perbaikan kinerja organisasi secara terus menerus yang mampu memenuhi harapan dan kebutuhan. Terkait dengan Tantangan Manajerial "Pengambilan keputusan yang cepat dan tepat" 
disadari oleh Kepala BKD Kaltim, hasil pemetaan BKD menyebutkan bahwa eselon II di Kaltim masih lemah dalam hal ini, apalagi terkait berbagai benturan kebijakan. Tantangan pemanfaatan teknologi informasi (TI) yang dianggap rendah oleh responden pimti dikarenakan masih rendahnya penguasaan TI tersebut di lingkungan pimti Pemprov Kalimantan Timur ini.

Urgensitas kompetensi Pengambilan keputusan yang cepat dan tepat bagi para pimpinan tinggi Kaltim disadari menjadi tantangan dalam mewujudkan agenda Nawacita. Upaya reformasi birokrasi, khususnya perbaikan pelayanan publik yang dilakukan pemerintah daerah menekankan pada pemberantasan korupsi.Tantangan pemberantasan praktik KKN menjadi salah satu tantangan terpenting di daerah. Tingginya kesadaran dan komitmen pemerintah daerah terhadap peningkatan pelayanan publik juga menjadikan tantangan "Tuntutan perbaikan kinerja organisasi secara terus menerus yang mampu memenuhi harapan dan kebutuhan pengguna layanan" dan "Membangun profesionalisme bawahan dalam menjalankan tugas" menjadi hal terpenting dalam mengintegrasikan Nawacita.

\section{Pengembangan Kompetensi Sosio Kultural}

Kemampuan memahami kearifan lokal dalam lingkungan paternalistik dan heterogenitas akan berbagai suku dan budaya, dianggap cukup berhasil dikembangkan di Provinsi Kalimantan Timur yang dibuktikan dengan hampir tidak adanya gejolak kesukuan atau kasus primordialisme yang mengancam Negara Kesatuan Republik Indonesia (NKRI). Adanya paguyuban yang dikoordinir oleh Gubernur sebagai Ketua Pembina cukup mampu mengelola perbedaan dan mencegah diskriminasi. Tidak hanya kearifan lokal juga kemampuan membaca situasi sebagai perangkat pendukungnya. Bagaimana memaknai keragaman jika pimpinan tidak arif atau tidak toleransi, yang berpotensi menjadi masalah dalam melaksanakan pembangunan. Pentingnya pimti memahami kemajemukan dan tidak menjadi pimpinan yang menimbulkan fiksi-fiksi tapi justru menghilangkan fiksi-fiksi itu sehingga antara pimpinan dan anak buah sejalan dan selaras dalam persepsi yang sama. Kemampuan memahami dan kelenturan budaya atau kelenturan persepsi terhadap budaya lokal juga dibutuhkan sebagai kompetensi sosio kultural pimti. Selain itu, prioritas kepemimpinan dibebankan kepada putra daerah terbaik meskipun disinyalir masih lemah dalam manajerial akan tetapi kemampuan mengelola keragaman budaya daerah itu menjadi kekuatan pemimpin di Kalimantan Timur. Ini juga dalam rangka mengurangi diskriminasi antara lulusan Jawa dan lulusan Kalimantan, terutama dalam pola rekrutmen saat ini.

Di sisi lain, kompetensi sosiokultural dalam hal kepekaan gender, Kaltim mendominasi jabatan struktural diisi oleh perempuan. Ini dapat dilihat salah satunya di BKD Provinsi Kaltim. Meskipun masih terdapat kelemahan manajerial dari pemangku jabatan pimpinan wanita diantaranya emosional, terlalu sensitif, pertimbangan yang lama disamping keuletan mereka. Kepekaan akan penyandang disabilitas telah diafirmasi dari adanya pemangku jabatan pimpinan yang berasal dari penyandang disabilitas.Memahami kompetensi sosiokultural ini tidak mudah, perlu tindakan aplikatif seperti mengunjungi taman makam pahlawan untuk menanamkan kebangsaan, kompetensi spiritual bukan dengan diajak berikrar anti korupsi tetapi dengan mempelajari dalam kehidupan nyata, mengunjungi orang miskin dan anak yatimpiatu, lansia, penyandang disabilitas dan sebagainya, kemudian dibuat surat penugasan kemudian hasil penugasan diseminarkan.

Kurangnya kompetensi sosio kultural berpotensi timbul gesekan konflik. Mendidik orangpun harus berdasarkan kebutuhan dan kompetensinya. Yang dibutuhkan adalah bagaimana membentuk pemimpin dengan kompetensi sosio kultural, manajerial, dan spiritual. Diklat aparatur diganti menjadi diklat kompetensi, atau diklat kinerja. Bagaimana menjawab kebutuhan akan pimpinan yang empatik, 
tauladan, di tengah menggerakkan, menjadi penyemangat, apapun namanya.Tidak hanya itu, pemimpin yang ideal itu harus benar-benar memahami konteks lokal sehingga tidak memubazirkan anggaran karena kemampuan komunikasi lintas sektoral dan lintas elemen (Dewi Sartika, 2015).

Selain itu corak dan ragam lingkungan daerah di Indonesia menjadikan lingkungan sosiokultural sebagai tantangan dalam mewujudkan agenda Nawacita. Terdapat lima tantangan lingkungan sosio-kultural menurut pimpinan tinggi Kaltim adalah (1) Masyarakat yang semakin menuntut adanya transparansi dan akuntabilitas dalam penyelenggaraan pemerintahan, (2) Masyarakat yang semakin akan hak-hak mereka dan menuntut kualitas pelayanan, (3) Membangun sinergi dengan stakeholder, (4) Ketidakpastian dinamika lingkungan politik, dan (5) Ketidakpercayaan masyarakat terhadap pemerintah yang meningkat.

Di era keterbukaan saat ini, masyarakat yang semakin sadar akan hak-haknya dan kritis terhadap kinerja pemerintahnya, menjadikan tuntutan transparansi dan akuntabilitas untuk penyelenggaraan pemerintahan menjadi tantangan penting bagi penyelenggara pemerintahan."Masyarakat yang semakin menuntut adanya transparansi dan akuntabilitas dalam penyelenggaraan pemerintahan” merupakan tantangan pengembangan sosio kultural yang Kalimantan Timur, hal ini dijawab upaya pencapaian kinerja laporan keuangan dengan opini Wajar Tanpa Pengecualian (WTP). Selain itu berbagai regulasi pengelolaan keuangan daerah dapat diakses di situs resmi pemerintah Kalimantan Timur (http:// www.kaltimprov.go.id/halaman-27-apbd-kaltim.html).

Tantangan masyarakat yang semakin sadar akan hak-hak mereka dan menuntut kualitas pelayanan serta membangun sinergitas dengan stakeholder dijawab Pemerintah dengan perbaikan dan pembangunan sarana prasarana, perbaikan mindset aparatur dan peningkatan budaya kerja organisasi, presensi manual dan online, penguatan budaya organisasi dan sebagainya.

\section{Hambatan dan Tantangan Pengembangan Kompetensi ASN}

Dalam pelaksanaan pengembangan kompetensi, terdapat beberapa aspek yang dianggap menjadi tantangan dan hambatan dalam upaya pengembangan kompetensiASN di Pemprov Kaltim, diantaranya adalah:

Dengan jumlah pegawai 70 ribu orang pegawai lebih, masih belum memenuhi kondisi ideal kompetensi pegawai Pemprov Kaltim. Dengan proporsi pegawai yang berkompeten sekitar 68 persen sisanya tidak kompeten. Disinyalir penyebabnya adalah dari kebijakan pusat.Pertama, rekrutmen sebelumnya dilakukan dengan pendekatan likuidasi instansi vertikal sekitar tahun 2001, di mana saat itu, pegawai yang semula 4.800 pegawai menjadi 11.000 pegawai. Kedua, menurut Kepala BKD, bahwa kebijakan penerimaan tenaga honorer dimana saat itu, Provinsi Kaltim menerima sekitar 2.000 pegawai untuk menjadi pegawai Pemprov. Ketiga, kebijakan lain yang mempengaruhi kompetensi dan upaya pembinaan yang harus dilakukan adalah adanya kebijakan untuk pengangkatan tenaga atlet menjadi PNS. Kebijakan rekruitmen pegawai yang bersifat top-down saat ini tidak tepat dilakukan, dan sebaiknya perekrutan pegawai sesuai kebutuhan pengembangan daerah. Dari 1.901 kebutuhan pegawai yang diusulkan Pemprov Kaltim tahun 2014, mendapatkan jatah/kuota 179 pegawai dimana sekitar 80 persen-nya diperuntukkan bagi tenaga pendidik, kesehatan, dan JFT, sedangkan 20 persen dari formasi untuk Jabatan Fungsional Umum (JFU) disebar di instansi teknis di lingkup Pemprov Kaltim seperti pertambangan, pertanian, perkebunan hingga keuangan. Pengusulan yang dilakukan berdasarkan hasil analisis jabatan dan analisis beban kerja, yang berpengaruh pada penyempurnaan kembali alokasi tugas, wewenang, dan tanggung jawab tiap jabatan sehingga akan berpengaruh kepada perbaikan sistem kerja dan rekrutmen pegawai profesional.Akan tetapi saat ini, tidak jelas apa yang menjadi kompetensi-nya, ditambah menjadi 
beban bagi BKD untuk membinanya. Sementara pertanyaannya adalah bagaimana kompetensinya, dengan dinamika aturan yang sangat tinggi, di sisi lain terkait kompetensi apa yang sudah disiapkan menjadi sia-sia karena konteksnya lokal. Kebijakan top down menjadi makin parah.Permasalahan berikutnya adalah masih berbelit-belitnya penilaian Jabatan Fungsional Tertentu (JFT) dan impassing. Ini akan ditindaklanjuti dengan asistensi rencana budjeting JFT.Selain itu, kebijakan pusat sering tidak berbasis data jadi kesannya reformasi ini masih prematur, belum jadi dan kebijakannya tidak membumi.

Hambatan dalam penyelenggaraan pengembangan kompetensi ini adalah inkonsistensi kebijakan. Pemerintah Pusat mengharapkan penerapan di daerah, seharusnya sudah diterapkan duluan di Pemerintah Pusat, serta jangan ada upaya mempolitisasi kebijakan. Selain itu, penerapan lelang jabatan masih menimbulkan masalah di lapangan. Instrumennya tidak disiapkan dengan baik oleh Pemerintah Pusat. Paradoks dengan di lapangan. Tapi BKD tetap taat aturan, salah satunya jika dalam 6 bulan tidak menunjukkan prestasi kinerja maka wajib dievaluasi.Selain itu, juga terkait pengangkatan dalam jabatan bagi mereka yang sudah dididik dalam jabatan yang akan diisi. Saat ini bahkan ada yang mencapai 5 (lima) tahun tapi belum diangkat dalam jabatannya, juga adanya calon pejabat yang ditawarkan dari luar, BKD telah menolak karena belum jelas track recordnya dan terindikasi menyalahgunakan jabatan (korupsi).

Merujuk data dari BKD Kaltim, pejabat pimti Kaltim saat ini rata-rata menunggu masa pensiun, diibaratkan gelas sudah penuh tidak dapat ditambah air lagi. Keseluruhan indikator tidak menonjol dan memperpanjang usia pensiun.Perludibuat register katalog semua pendidikan se-Indonesia sehingga rekomendasi lembaga pendidikan dan pelatihan untuk kompetensi tertentu sudah jelas, ada lembaga sertifikasinya, ada asesornya, dan jelas instrument pengukurannya.Dengan demikian, output alumni diklat, jelas keahliannya.Hambatan mental block harus dihilangkan. Konstrain anggaran bukan menjadi hambatan utama tetapi patut dicoba metode lain dengan magang di instansi lain. Perluinovasi jangan mau membebek. Dan, sesuaikan dengan konteks lokal. Jadi tidak ada lagi output yang tidak pas karena tiadanya kapasitas yang tepat/ bukan ahlinya. Demikian pernyataan Kepala BKD Provinsi Kaltim dalam wawancara.

\section{E. PENUTUP}

Berdasarkan uraian sebelumnya, maka dapat disimpulkan bahwa:

1. Penerapan pengembangan kompetensi berdasarkan Undang-undang No 5 Tahun 2014 tentang ASN sudah diterapkan pemerintah daerah Provinsi Kalimantan Timur, meskipun untuk pengembangan kompetensi khususnya pimti masih dianggap menjadi ranah institusi BKD belum menjadi prioritas kebutuhan daerah berbasis regional content bukan hanya berbasis pemenuhan kebutuhan mendasar organisasi, pengelolaan kinerja dan pengembangan kompetensi masih dibatasi minimnya anggaran dan tenaga pengelola, serta kebijakan pusat yang inkonsisten.

2. Melihat dimensi postur kepegawaian pada pemerintah Provinsi Kalimantan Timur, rata-rata jumlah pemangku pimpinan tinggi (pimti) dengan rasio pimti perempuan dan akomodir putra daerah masih kecil. Dimensi kelembagaan/ layanan publik di lokus diteliti menunjukkan inovasi pelayanan publik yang lebih baik ditandai dengan reformasi sistem pelayanan publik.

3. Dari hasil analisa, diperoleh gambaran bahwa tantangan manajerial yang relatif paling menonjol pada pimpinan tinggi di lingkungan Pemerintah Daerah di Kalimantan Timur adalah pengambilan keputusan yang cepat dan tepat, pemberantasan praktik korupsi, kolusi dan nepotisme, membangun profesionalisme bawahan dalam menjalankan tugas, dan tuntutan perbaikan kinerja organisasi secara terus menerus yang mampu memenuhi harapan dan pengguna layanan. Adapun 
temuan kompetensi manajerial relevan/gap adalah pengambilan keputusan, kerja sama (team building), dan berorientasi pada kualitas. Sedangkan tantangan kompetensi sosio-kultural pimpinan tinggi yang secara umum ditemukan di lingkungan Pemerintah Daerah di Kalimantan Timur adalah masyarakat yang semakin menuntut adanya transparansi dan akuntabilitas dalam penyelenggaraan pemerintahdan masyarakat yang semakin sadar akan hak-hak mereka dan menuntut kualitas pelayanan, membangun sinergi dengan stakeholder, ketidakpastian dinamika lingkungan politik dan ketidakpercayaan masyarakat terhadap pemerintah yang meningkat. Adapun relevansi/gap relatif rendah. Ini menunjukkan bahwa perlunya penyusunan standar kompetensi manajerial dan sosio kultural pemangku jabatan pimpinan tinggi (JPT), bukan hanya yang mampu memberikan nilai tambah bagi organisasi akan tetapi juga memberikan nilai kompetitif bagi pemangku kepentingan /stakeholder, mudah dilaksanakan dan dapat menunjukkan hasil yang cepat.

Berdasarkan analisis terhadap hasil penelitian diperoleh rekomendasi sebagai berikut:

1. Agar penerapan model/standar kompetensi khususnya bagi pejabat pimpinan tinggi dapat memberikan nilai kompetitif, dalam proses pengembangannya harus direncanakan dengan baik dan harus selaras dengan misi, strategi, tantangan maupun sasaran yang ingin dicapai oleh organisasi serta, berbasis regional content.

2. Perlunya assesment kepada pemangku jabatan pimpinan tinggiterhadap kompetensi yang dianggap relevan dan dibutuhkan tersebut untuk ditindaklanjuti dengan kegiatan pengembangan kompetensi terkait. Yang diikuti dengan menyusun standar kompetensi manajerial dan kompetensi sosiokultural pemangku jabatan pimpinan tinggi berdasarkan hasil temuan kompetensi yang diperoleh untuk selanjutnya menjadi benchmark dalam pengembangan kompetensi pimti di daerah lain.

3. Dari beberapa faktor yang mempengaruhi pengembangan kompetensi pejabat pimpinan tinggi Kaltim, hendaknya tidak hanya memperhatikan prioritas putra daerah akan tetapi juga visi pengembangan daerah kedepannya/konteks lokal kedaerahan, penguatan kapasitas pimpinan tinggi-pun sebaiknya didasarkan pada sasaran strategis dan IKU yang telah ditetapkan.Perlunya regenerasi kepemimpinan yang dinamis, pemetaan kompetensi pimti (mapping talent pool), dengan memperhatikan kepekaan gender dan prioritas putra daerah berbasis regional content dan tepat sasaran sesuai kebutuhan.Perlunya memasukkan program pengembangan kompetensi ASN khususnya pimti baik manajerial maupun sosiokultural dalam prioritas pembangunan daerah.

4. Dalam upaya membangun pengembangan kompetensi pimti yang terukurdan tepat sasaran serta unjuk kerja kolektif, perlu membuat laboratorium inovasi di setiap daerah sebagai proyek perubahan berkelanjutan setiap pimti di unit kerjanya. Kemudian, pelaporan kinerja pimti dimuat dalamSistem Informasi Aparatur Sipil Negara.

5. Dikarenakan keterbatasan penelitian ini, ke depannya dapat dilakukan kajian sejenis dengan lingkup penelitian yang lebih luas.

\section{DAFTAR PUSTAKA}

(NLCM), N. L. (2017, 05 21). https://www.netc.navy.mil/centers/cppd/News.aspx?ID=0. Retrieved 05 21, 2017, from https://www.netc.navy.mil: https://www.netc.navy.mil/centers/ cppd/News.aspx?ID $=0$

Abdussamad, Y. (2017). Pengembangan Sumber Daya Manusia Aparatur Melalui Kompetensi. Jurnal Ekonomi dan Bisnis Universitas Negeri Gorontalo, 6. 
Birokrasi, K. P.-R. (2017, Maret 13). Retrieved Juni 15, 2017, from Kementerian Pendayagunaan Aparatur Negara - Reformasi Birokrasi.

BKD. (2009, Juli 30). BKD Provinsi Kaltim. Retrieved Maret 20, 2017, from http://kaltimbkd.info/ index.php/id/informasi-kepegawaian/info-lainnya/206-rekap-jumlah-aparatur

BKD. (2014, Mei 13). Retrieved Maret 13, 2017, from http://kaltimbkd.info/index.php/id/beritadan-artikel/berita-prov/2512-pemetaan-dan-pengembangan- karir-pns

BKD. (2015, April 16). Retrieved Maret 2017, 16, from http://kaltimbkd.info/index.php/id/beritadan-artikel/berita-prov/2763 -pemetaan-potensi-pns-di-lingkungan-pemprov-kaltim

BKD. (2015, Januari 29). Retrieved Maret 12, 2017, from http://kaltimbkd.info/index.php/id/beritadan-artikel/berita-prov/2763 -pemetaan-potensi-pns-di-lingkungan-pemprov-kaltim

BKD. (2016, Mei 27). Retrieved Maret 04, 2017, from http://kaltimbkd.info/index.php/id/beritadan-artikel/berita-prov/3482-kaltim-raih-anugrerah-bkn-award-2016

BPS. (2017, Maret 12). BPS Kaltim. Retrieved Maret 12, 2017, from https://kaltim.bps.go.id/ linkTableDinamis/view/id/52

BPSDM. (2014, September 19). Retrieved Maret 12, 2017, from http://bpsdm.kaltimprov.go.id/ read/news/2014/666/pemprov-kaltim-bentuk-team-building-trasformasi-dan-budaya-kerja

Bungin, M. B. (2007). Penelitian Kualitatif : Komunikasi, Ekonomi, Kebijakan Publik, dan Ilmu Sosial Lainnya. Jakarta: Kencana Prenada Media Group.

Dewi Sartika, d. (2015). Pengembangan Kompetensi Aparatur Sipil Negara. Samarinda: Pusat Kajian dan Pendidikan dan Pelatihan Aparatur III.

Fadilla Astra, J. M. (2016). Pengaruh Pendidikan dan Pelatihan Struktural terhadap Kompetensi Kepemimpinan Aparatur Sipil Negara Studi di Sekretariat Daerah Kota Bitung. Retrieved Maret 13, 2017, from https://ejournal.unsrat.ac.id/index.php/JAP/article/view/ 13939

Hadi Shubhan, E. d. (2014). Competence Enhancemenet of Government Apparatus in Public Service of Regional Areas. IOSR Journal Of Humanities And Social Science (IOSR-JHSS), 1416.

Indonesia, R. (n.d.). Undang-Undang Nomor 5 Tahun 2014 tentang Aparatur Sipil Negara.

Jordan, A. (2010). Competency Development. Jordan: AIESEC Jordan.

KEMENPAN-RB. (2017, Maret 13). Retrieved Maret 15, 2017, from (https://www.menpan.go.id/ berita-terkini/6579-asn-pengisi-setiap-jabatan-harus-memiliki-kompetensi-dan-sertifikasikeahlian diunduh 15 Juni 2017

KEMENPAN-RB. (2017, Mei 19). Retrieved Juni 15, 2017, from https://www.menpan.go.id/ berita-terkini/6926-pengembangan-asn-perlu-komitmen-pimpinan

Kementerian Pendayagunaan Aparatur Negara dan Reformasi Birokrasi. (2014). TOP 99 Inovasi Pelayanan Publik Indonesia Tahun 2014. Indonesia: Kementerian Pendayagunaan Aparatur Negara dan Reformasi Birokrasi. 
Koeswayo, D. I. (2014). Effect Of Government Apparatus Competence And The Effectiveness Of Government Internal Control Toward The Quality Of Financial Reporting And Its Impact On The Performance Accountability In Local Government (Survey Of All Units Local Government In Tegal City.South East Asia Journal of Contemporary Business, Economic and Law, 90-100.

Nazir, M. (2014). Metode Penelitian. bogor: Ghalia Indonesia.

Palan, R. (2003). Competency Management, A Practitioner's Guide. Malaysia: Specialist Management Resources Sdn Bhd (Co.no. 385604-V) 14-4.

Rahmad. (2015, Maret 19). Retrieved Maret 20, 2017, from http://www.antarakaltim.com/berita/ 24498/pemprov-kerja-sama-dengan-lan-ri

Rosianton Herlambang, A. I. (2014). Implementasi Pengembangan Kompetensi Sumber Daya Manusia Dalam Meningkatkan Kinerja Pegawai Di Kantor Camat Bontang Barat Kota Bontang. eJournal Administrative Reform, 859-870.

Veithzal Rivai Zainal, M. R. (2015). Manajemen Sumber Daya Manusia untuk Perusahaan Dari Teori ke Praktik. Jakarta: PT Raja Grafindo Persada.

Wirantha, H. H. (2012). Pengolahan dan Analisis Data (Bidang IPS). Bogor: LIPI, Cibinong. 
